\title{
Intramuscular Myxoma of the Right Cruris: A Case Report
}

\begin{tabular}{|c|c|}
\hline \multicolumn{2}{|c|}{$\begin{array}{l}\text { (D) Alican Barış, (D) Esra Circi } \\
\text { University of Health Sciences Turkey, İstanbul Training and Research Hospital, Clinic of Orthopaedics and Traumatology, İstanbul, Turkey }\end{array}$} \\
\hline ABSTRACT & ÖZ \\
\hline $\begin{array}{l}\text { Intramuscular myxoma is one of the rare soft tissue benign } \\
\text { tumours. The most common localisation of the myxoma is the } \\
\text { heart muscle. It has been reported less frequently in the hip } \\
\text { and around the shoulder, trunk, neck and cruris. We aimed to } \\
\text { report this rare case of the cruris. }\end{array}$ & $\begin{array}{l}\text { İntramusküler miksoma yumuşak dokunun iyi huylu nadir } \\
\text { tümörlerinden biridir. Miksomanın tipik yerleșim yeri kalp } \\
\text { kasıdır. Kalça, omuz çevresi, gövde, boyun ve bacakta daha az } \\
\text { rastlanmaktadır. Bacakta görülen bu nadir olguyu bildirmeyi } \\
\text { amaçladık. }\end{array}$ \\
\hline Keywords: Benign tumour, cruris, intramuscular myxoma & $\begin{array}{l}\text { Anahtar Kelimeler: İyi huylu tümör, bacak, intramusküler } \\
\text { miksoma }\end{array}$ \\
\hline
\end{tabular}

\section{Introduction}

Intramuscular myxoma is a rare benign soft tissue tumour of mesenchymal origin surrounded by muscular tissue $(1,2)$. Myxomas are slow-growing tumours. They are most commonly localised in the heart muscle, while other rare cases were detected within the muscle tissue of the extremities. It has been reported less frequently in the hip and around the shoulder, trunk, neck and cruris (3). It is observed more frequently among women in the fourth to sixth decades $(4,5)$. Therefore, we aimed to report this rare case.

\section{Case Report}

Informed consent was obtained from the patient for the case presentation below. A 56-year-old female patient was evaluated for pain and swelling in the right cruris. The patient had been suffering from this complaint of swelling for six months, with the addition of pain for the last month. On physical examination, the lesion was found to be firm, mobile and painful. The patient was evaluated by ultrasonography and magnetic resonance imaging. The mass was found as well-circumscribed with homogenous signal intensity, located on the proximal cruris anteriormedial side in the subcutaneous fat tissue and having a size of $24 \times 64$ $\mathrm{mm}$ The lesion was demonstrated by $\mathrm{T} 1$ weighted sequences low signal intensity and $\mathrm{T} 2$ fat suppressed sequences high signal intensity in the magnetic resonance imaging. The mass, which was distinct from the surrounding tissues, was excised in the form of an en-block with a narrow margin using a longitudinal incision (Figure 1). Histopathology demonstrated a tumour consisting of spindle- and stellate-shaped cells embedded within loose fibrous and myxoid stroma. It was found to be moderately well-circumscribed. Atypical cytologic features and mitotic figures were not detected. The lesion contained fatty tissue areas separated by fibrous bands in the fibroadipous tissues. This benign lesion was defined as a myxoma. The pain and cosmetic complaints

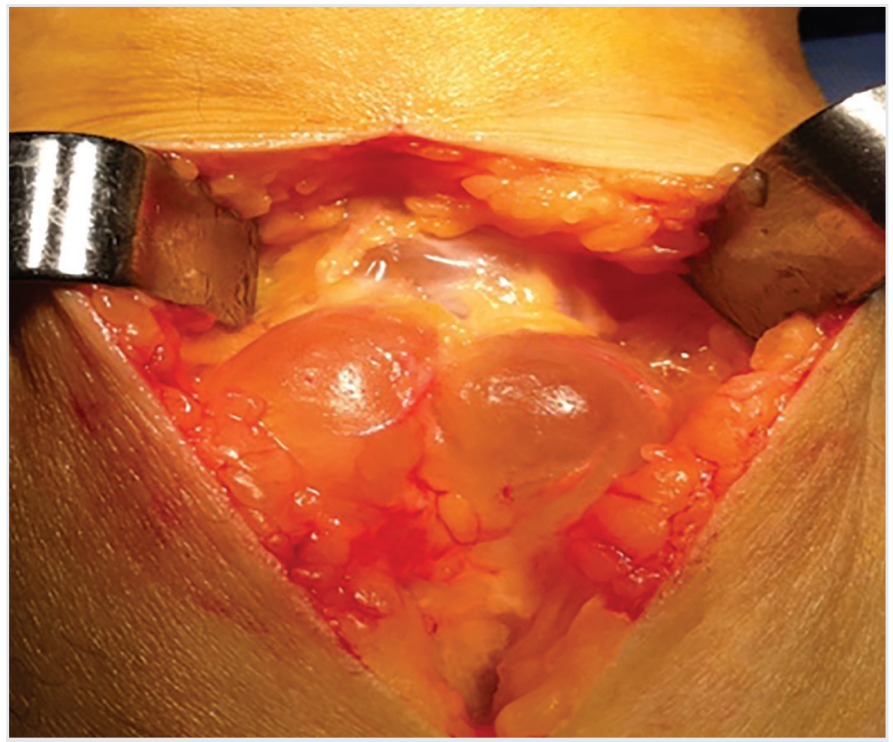

Figure 1. Intramuscular myxoma view during surgery
Address for Correspondence/Yazıșma Adresi: Alican Barıș MD, University of Health Sciences Turkey, İstanbul Training and Research Hospital, Clinic of Orthopaedics and Traumatology, İstanbul, Turkey

Phone: +90 5324101881 E-mail: dralicanbaris@gmail.com ORCID ID: orcid.org/0000-0001-6031-6777

Cite this article as/Atıf: Barıș A, Circi E. Intramuscular Myxoma of the Right Cruris: A Case Report. İstanbul Med J 2020; 21(Suppl 1): 4-5.
Received/Geliș Tarihi: 21.12.2019 Accepted/Kabul Tarihi: 12.02 .2020

(C) Copyright 2020 by the University of Health Sciences Turkey, Istanbul Training and Research Hospital/istanbul Medical Journal published by Galenos Publishing House.

(C) Telif Hakkı 2020 Sağlık Bilimleri Üniversitesi Istanbul Ĕgitim ve Araştırma Hastanesi/Istanbul Tıp Dergisi, Galenos Yayınevi tarafından basılmıștır. 
were resolved after the surgery. It is thought that the pain complaint may have resulted from the local pressure effect of the mass. Physical examination did not observe any recurrences of the mass during the 2-year postoperative follow-up.

\section{Discussion}

Benign and malignant soft tissue tumour, haematoma and abscess should be considered in the differential diagnosis. The intramuscular myxoma has not been observed in the presence of cellular atypia, increased mitotic activity and rapid growth (6). The separation of the borders from the surrounding muscle tissue in the radiological evaluation helps in the differential diagnosis (7). The relationship between intramuscular myxoma and fibrous dysplasia is known. Mazabraud's syndrome is a rare syndrome in which benign intramuscular myxoma occurs in association with a monostotic or polyostotic form of fibrous dysplasia on the bone $(8,9)$. It may accompany the McCune Albright syndrome (10). Complete excision with narrow margins is advised. The researcher revealed the occurrence of local recurrence in association with the incompletely excised tumours. Metastases and a locally aggressive behaviour have not been observed. Neoadjuvant and adjuvant treatment were not recommended (11).

Intramuscular myxoma should be considered in the differential diagnosis of soft tissue lesions of the lower extremities.

\section{Ethics}

Informed Consent: Informed consent was obtained from the patient for the case presentation below.

Peer-review: Externally peer-reviewed.

Authorship Contributions: Surgical and Medical Practices - E.C.; Concept - A.B., E.C.; Design - A.B.; Data Collection or Processing - A.B., E.C.; Analysis or Interpretation - E.C.; Literature Search - A.B., E.C.; Writing - A.B.
Conflict of Interest: No conflict of interest was declared by the authors.

Financial Disclosure: The authors declared that this study received no financial support.

\section{References}

1. Domino JS, Weindel $S$, Woodrow $S$. Multiple paraspinal intramuscular myxomas: case report. J Neurosurg Spine 2019; 32: 491-632.

2. Custódio M, Antunes E, Alves G, Braz-Silva P. Unexpected diagnosis of an intramuscular myxoma arising from the masseter muscle. Br J Oral and Maxillofac Surg 2002; 58: 109-11.

3. Tirefort J, Kolo FC, Lädermann A. An Interesting Case of Intramuscular Myxoma with Scapular Bone Lysis. Case Rep Orthop 2017; 2017: 1690409

4. Silver WP, Harrelson JM, Scully SP. Intramuscular myxoma: a clinicopathologic study of 17 patients. Clin Orthop Relat Res 2002: 191-7.

5. Enzinger FM. Intramuscular myxoma: a review and follow-up study of 34 cases. Am J Clin Pathol 1965; 43: 104-13.

6. Bekers EM, Eijkelenboom A, Rombout P, van Zwam P, Mol S, Ruijter E, et al. Identification of novel GNAS mutations in intramuscular myxoma using next-generation sequencing with single-molecule tagged molecular inversion probes. Diagn Pathol 2019; 14.

7. Wang W, Smitaman E, Rubenstein W, Hughes T, Huang BK. Post-biopsy MRI changes in the size and enhancement of intramuscular myxomas: A report of two cases. Clin Imaging 2018; 48: 55-61.

8. Jalan D, Jain P. Mazabraud's Syndrome-A Diagnosis Commonly Missed. J Orthop Case Rep 2019; 9: 26-9.

9. Majoor B, van de Sande M, Appelman-Dijkstra N, Leithner A, Jutte P, Vélez R, et al. Prevalence and clinical features of Mazabraud's syndrome: a multicentre European survey. J Bone Joint Surg Am 2019; 101: 160-8.

10. Macfarlane P, Lew W, Neuhaus S. An aggressive case of Mazabraud's syndrome. Eur J Surg Oncol 2007; 33: 1087-9.

11. Fetsch JF, Laskin WB, Miettinen M. Superficial acral fibromyxoma: a clinicopathologic and immunohistochemical analysis of 37 cases of a distinctive soft tissue tumor with a predilection for the fingers and toes. Hum Pathol 2001; 32: 704-14. 